\title{
Trade-offs in prey quality and quantity revealed through the behavioral compensation of breeding seabirds
}

\author{
Michael B. Schrimpf ${ }^{1, *}$, Julia K. Parrish ${ }^{1}$, Scott F. Pearson ${ }^{2}$ \\ ${ }^{1}$ School of Aquatic and Fishery Sciences, Box 355020, University of Washington, Seattle, Washington 98195, USA \\ ${ }^{2}$ Wildlife Research Division, Washington Department of Fish and Wildlife, Olympia, Washington 98501, USA
}

\begin{abstract}
Many productive ocean ecosystems are also highly variable, resulting in complex trophic interactions. We analyzed interannual patterns in the diet of a seabird, the common murre Uria aalge, in a region of high oceanographic productivity, the northern California Current, to investigate how these top predators adjust their chick provisioning to cope with environmental variability. Murres relied chiefly on Pacific herring Clupea harengus pallasi and surf smelt Hypomesus pretiosus to provision chicks, although they regularly returned 8 other fish taxa. Provisioning success was measured by the energy return rate to chicks, which in turn was disarticulated into energy per meal (quality) and meal delivery rate (quantity). Parents exhibited 'compensation' during 2 years in which smaller, low quality prey were returned more quickly than in years with normal (i.e. 'good') provisioning. Despite the increased delivery rate, energy return rates were still lower in 'compensation' vs. 'good' years. The lowest energy return rates occurred in 3 'poor' years, during which ocean productivity was also depressed. Our results suggest that murres in this system have the ability to shift provisioning strategies to deal with some variability in prey resources, but not when limited by exceptionally poor environmental conditions.
\end{abstract}

KEY WORDS: Foraging behavior - Seabird diet · Provisioning rate $\cdot$ Environmental variability · Common murre $\cdot$ Uria aalge $\cdot$ Northern California Current

\section{INTRODUCTION}

In the California Current System, changes in the strength and timing of upwelling create order-ofmagnitude changes in primary productivity (Hickey 1998, McGowan et al. 1998) that in turn impact zooplankton (Mackas et al. 2004, 2007) and fish (Brodeur et al. 2005, Ware \& Thomson 2005) communities. Such dramatic bottom-up shifts in prey resources can impact the foraging behavior and breeding success of long-lived, higher trophic level predators such as marine mammals (Boyd et al. 1994, Skern-Mauritzen et al. 2009) and seabirds (Ainley et al. 1996, Sydeman et al. 2006, Ronconi \& Burger 2008). By definition, long-lived top predators must be able to cope with changes in prey resources as a consequence of bottom-up forcing, with either individual or population level adaptability (Lack 1968, Ashmole 1971). Understanding the nuances of this adaptability, particularly when it is short-term and/or behavioral in nature, allows scientists and managers to better describe ecosystem interactions. Cairns (1987) suggested that seabird population dynamics should exhibit nonlinear relationships with changes in prey availability, where vital rates (e.g. reproductive output, survivorship) should be sensitive to small shifts when prey are scarce, and behavioral rates (e.g. foraging effort) should change when prey are more abundant. In testing Cairns' predictions, Harding et al. (2007) and Piatt et al. (2007) showed that in some cases feeding 
rates or time spent foraging did exhibit non-linear relationships with prey availability, suggesting that some measures of foraging behavior reflect environmental quality and, by extension, the degree of bottom-up forcing.

Prey availability, considered broadly, is a suite of interacting variables collectively shifting the prey landscape that seabirds face. The abundance and quality (i.e. size and energy density) of different species all contribute to the availability of suitable prey. Studies in which shifts in the relative abundance of different prey taxa result in shifts in seabird nestling diet are common (e.g. Bryant et al. 1999, Gaston et al. 2003, Miller \& Sydeman 2004, Hipfner 2009), but studies that focus on prey quality are less common. One exception is a study by Davoren \& Montevecchi (2003), who reported that an increase in the proportion of immature, and therefore smaller, capelin Mallotus villosus negatively affected the condition of common murre Uria aalge chicks in Newfoundland. More subtly, Wanless et al. (2005) found that significant interannual changes in the energy density of individual size-corrected prey (North Sea sandeels Ammodytes marinus) resulted in reduced chick growth and survival among common murres.

Some seabird species utilize different foraging strategies to compensate for prey variability. Compensation can take a variety of forms, such as a bimodal foraging strategy (Chaurand \& Weimerskirch 1994, Weimerskirch et al. 2003, Welcker et al. 2009a), individual differences in foraging habitats (Elliott et al. 2008b, 2009), or simply an increase in trip duration and/or foraging distance (Suryan et al. 2002, Burke \& Montevecchi 2009, Pichegru et al. 2010). In some cases adults expend more energy to increase feeding rates and/or take higher quality prey (Jodice et al. 2006, Deagle et al. 2008, Welcker et al. 2009b; but see Welcker et al. 2010). To successfully fledge chicks, any seabird must ultimately maintain a minimum rate of energy (calories from food) delivery to the colony. From the offspring's perspective, therefore, energy delivery rate can be treated as a provisioning currency, and this has been used to measure the net result of provisioning (Lewis et al. 2003, Weimerskirch et al. 2003, Jodice et al. 2006). Energy return rate to chicks can be disarticulated into 2 variables: (1) energy per meal, reflecting the type and quality of prey, and (2) meal delivery rate, relating both the quantity of prey delivered and the time invested in provisioning.

This study used the relationship between chick energy per meal and meal delivery rate to explore whether adult seabirds exhibited different provision- ing strategies to maximize chick energy return rate. We hypothesized that a trade-off between energy per meal and meal delivery rate would be present during periods when energy delivery rate was high. Suryan et al. (2002) suggested that in seabirds, a threshold would separate conditions in which adults could adjust provisioning behavior from conditions in which environmental variability limited their ability to do so. During years with poor environmental conditions, we expected to see a decrease in chick energy delivery rate.

To test these hypotheses we used a $14 \mathrm{yr}$ chick diet data set from common murres Uria aalge (hereafter: murres) nesting on Tatoosh Island, Washington State, USA $\left(48^{\circ} 23.5^{\prime} \mathrm{N}, 124^{\circ} 44.2^{\prime} \mathrm{W}\right)$, a collection of rocky islets (total land area about 6 ha; Paine et al. 1990) approximately $0.6 \mathrm{~km}$ off the tip of the Olympic Peninsula (Zador et al. 2009). The island sits at the mouth of the Strait of Juan de Fuca, a region with a complex prey field (Brodeur et al. 2005, Emmett et al. 2006) and high variability in ocean productivity (Hickey 1998, Hickey \& Banas 2003). Although common murres in other systems appear to rely primarily on single (Davoren \& Montevecchi 2003) or dual (Miller \& Sydeman 2004, Wanless et al. 2005) prey species, in the northern California Current murres are catholic foragers, regularly returning several prey species to their chicks (Parrish \& Zador 2003). This system provided adult murres ample opportunities for utilizing different provisioning strategies under a range of environmental conditions.

\section{MATERIALS AND METHODS}

\section{Data collection}

Breeding murres nest in several isolated subcolonies on Tatoosh Island, 2 of which were observed during short (approximately 3 to $10 \mathrm{~d}$ ) sampling trips throughout the breeding season (late May through early September) from 1996 to 2006 and in 2009. Disturbances by bald eagles Haliaeetus leucocephalus caused complete breeding failure at egg laying in 2007 and 2008 (J. K. Parrish unpubl. data), which precluded the observation of chick provisioning. Observations of murres were made from blinds immediately adjacent to nesting birds. All of the reproductive pairs in plots (approximately 4 to $6 \mathrm{~m}^{2}$ ) surrounding the blinds were mapped at the beginning of each season.

Prey fed to chicks were observed in hour-long 'fishwatches', spaced throughout the daylight hours in 5 
standardized time slots, beginning at 06:00, 09:00, 12:00, 15:00, and 18:00 $\mathrm{h}$, and sampled evenly across each trip and the season as a whole. During a fishwatch, every prey item brought back to a chick in the fish-watch plot was logged to the minute. Provisioning rate (number of fish chick $^{-1} \mathrm{~h}^{-1}$ ) and energy return rate $\left(\mathrm{KJ} \mathrm{chick}^{-1} \mathrm{~h}^{-1}\right)$ were calculated as watchspecific averages across all chicks within the plot, and varied as a function of time-of-day, season, year, and chick age. Potential biases in annual averages from time-of-day and seasonal differences were minimized to the extent possible by the uniform sampling distribution. This plot-based method provided a 'big-picture' view of murre provisioning, instead of the individual-based approach used in many other studies (e.g. Wanless et al. 2005, Hipfner et al. 2006). One benefit to this approach is that it includes multiple returns from many pairs, helping to mitigate the confounding effects of sex (Thaxter et al. 2009) and individual specialization (Elliott et al. 2009).

Fish were identified to the lowest possible taxon, usually species. There were several multiple-species categories; however, only 4 such groups comprised an appreciable (i.e. $>1 \%$ ) proportion of the total diet (see Supplement S4 at www.int-res.com/articles/suppl/ m460p247_supp.xls): cod (Gadidae), Pacific salmon (Salmonidae), lanternfish (Myctophidae), and rockfish Sebastes spp. Based on clearly seen fish returned by the murres, fish samples from concurrent rhinoceros auklet Cerorhinca monocerata diet studies on Tatoosh, and trawl surveys (J. K. Parrish unpubl. data), cod likely included Pacific cod Gadus macrocephalus, Pacific hake Merluccius productus, Pacific tomcod Microgadus proximus, and walleye pollock Theragra chalcogramma; salmon likely included steelhead (Oncorhynchus mykiss), chinook (O. tshawytscha), coho (O. kisutch), pink (O. gorbuscha), chum $(O$. keta), and sockeye (O. nerka) salmon. The lanternfish and rockfish groups likely contained many species, but were never identifiable beyond the family or genus level, respectively. Smelts (Osmeridae) and clupeoids (Clupeiformes; e.g. herring and anchovies) were usually identifiable to species, but were occasionally only seen well enough for identification to group, and were therefore placed in nested categories. When observers could not identify a fish to group, usually because it was not seen well, it was labeled as 'unidentified' $(5.5 \%$ of all samples, and never more than $8.4 \%$ in any single year; see Supplement S4 for more details). Unidentified fish may have been rare fish species, but more likely they represented a variety of species common in the diet that were simply obscured from view. Fish in the unknown, smelt, and clupeoid categories were dropped for the principal component analysis (PCA), because they represent nested categories of other species already in the analysis. They were included in the calculation of total energy per fish and provisioning rate, however.

Fish length (total length: from snout to end of tail) was estimated by comparing the length of the fish to the length of the murre's bill, from gape to rostrum (72 mm), assuming the nose of the fish was approximately at the gape (Parrish \& Zador 2003). Fish were estimated to the nearest quarter bill length, because of the subjective nature of this estimation procedure. It is possible that fish lengths were underestimated with this method, as found by Elliott et al. (2008a). If present, this bias would have no effect on the timeseries analyses presented in the present study, but would need to be considered when compared with results from other studies.

A total of 16 observers collected data over the course of the study. New observers were trained in situ in fish identification by collecting data with an experienced observer, comparing each identification after the fact. Once disagreements dropped below $5 \%$, novice observers were allowed to collect data independently. Three out of 12 yr exhibited small, but statistically significant differences in the mean length of fish recorded by different individual observers (1999, 2000, and 2003; ANOVA: $\mathrm{p}_{1999}=0.038, \mathrm{p}_{2000}<0.001$, $\mathrm{p}_{2003}<0.001$ ). In such cases, removing all records from the observer in question for that year resulted in less than a $5 \%$ change in the annual mean fish length, so observer bias was considered negligible and data from all observers were left in the analysis.

\section{Calculation of total energy}

Energy content of each fish was calculated from species-specific energy density and the estimated weight of the fish. Fish length was converted to wet weight using allometric relationships established from fish in hand (using linear regressions of logtransformed values; $\alpha<0.05$; see Supplement S1) and/or literature values (Haynes \& Wigley 1969, Froese \& Pauly 2010), and total energy was calculated by multiplying wet weight by a single estimate of energy density for each taxonomic group. Energy densities were either determined by bomb calorimetry (Parr 1425 semimicro calorimeter) or obtained from literature sources (Haynes \& Wigley 1969, Van Pelt et al. 1997, Anthony et al. 2000, Hunt et al. 2005, Froese \& Pauly 2010; see Supplements S1, S2 \& S3 for the list of sources and parameters for each species). Fish pro- 
cessed for calorimetric analysis were first oven-dried at $70^{\circ} \mathrm{C}$ until weight remained constant. Dried samples were individually homogenized with a mortar and pestle, and 3 pellets of the resulting fish meal were bombed to calculate an average energy density for each sample.

Energy density of surf smelt Hypomesus pretiosus and Pacific sandlance Ammodytes hexapterus increased linearly with length (surf smelt: $r^{2}=0.620$, $\mathrm{p}<0.001$; sandlance: $\left.\mathrm{r}^{2}=0.667, \mathrm{p}<0.001\right)$. Both Pacific herring Clupea harengus pallasi and northern anchovy Engraulis mordax showed step-wise length vs. energy density patterns, with the step at lengths corresponding to the age- 0 to age- 1 transition described in the literature (herring: $120 \mathrm{~mm}_{\mathrm{SL}}$, Foy \& Paul 1999; anchovy: $95 \mathrm{~mm}_{\mathrm{SL}}$, Hart 1973, Litz et al. 2008). Above the transition, both species had a much higher and more variable energy density that was not related to length (herring: $r^{2}=0.00, p=0.907$; anchovy: $\mathrm{r}^{2}=0.00, \mathrm{p}=0.988$ ); below the transition, the relationship between length and energy density was linear and significant for herring $\left(\mathrm{r}^{2}=0.88, \mathrm{p}<\right.$ $0.001)$, and relatively more noisy for anchovy $\left(\mathrm{r}^{2}=\right.$ $0.30, \mathrm{p}=0.158$ ) probably due to low sample size $(\mathrm{N}=8)$. Tirelli et al. (2006) found a similar relationship between length and energy density for European anchovy $E$. encrasicolus with a similar stepwise increase in variability (corresponding to the transition into breeding-age fish). We therefore used the age-class transitions from the literature to separate herring and anchovy into age-0 and age-1+ categories for estimation of energy density.

\section{Species composition analysis}

For comparison of taxonomic composition, a species (or species group) was considered a major component of the diet if it made up at least $5 \%$ of the total diet in any single year. To examine interannual similarities in dietary diversity, we used a PCA on fish abundances, which were first standardized 'by the norm', following McCune \& Grace (2002). We minimized the potential confounding effect of group heterogeneity by pooling all non-major prey categories into a single 'other' category (McCune \& Grace 2002).

\section{Confounding effect of young chicks}

Considering chick age was necessary, due to the potential for adult seabirds to adjust prey size based on the different food requirements of chicks of different sizes (Bertram et al. 1996, Suryan et al. 2002, Paiva et al. 2006). To that end, hatch date was recorded for each chick when possible. For chicks that hatched during periods when researchers were not on the island, hatch date was estimated by forward calculation from the lay date (average incubation period on Tatoosh is $32 \mathrm{~d}$; J. K. Parrish unpubl. data). When lay date was also unobserved, the most likely hatch date was estimated from among the range of missing observations, taking into consideration the chick's stage of development when first observed. Due to uncertainty in this method, chick age was binned by week.

Chicks within a week of hatching were fed smaller fish on average than all other $1 \mathrm{wk}$ age classes in all years (ANOVA: $F_{3,9702}=89.8, \mathrm{p}<0.001$; Tukey's HSD post hoc test: $\mathrm{p}<0.001$ for each pairwise comparison: chicks aged 1 wk vs. 2, 3, and 4 wk). Because fishwatches had variable numbers of young $(<1 \mathrm{wk})$ chicks, all young chicks were removed from the calculation of prey size, provisioning rate, energy per meal, and energy return rate. Returns to chicks of both age groups were included in the analysis of interannual prey taxonomic composition.

\section{Physical forcing}

Due to the complex nature of the environment around the colony (Hickey 1998, Hickey \& Banas 2003), we expected that variation in murre diet might reflect physical forcing across a gradient of time and space (Parrish \& Zador 2003). Therefore, oceanographic indices were collected that were known to be correlated with primary productivity from local to basin-wide spatial scales and from seasonal to annual temporal scales. Several indices were averaged across 2 seasonal periods each year: spring (March to May) and summer (June to August). This measure of spring captures the time period when seasonal upwelling begins in the Pacific Northwest (Holt \& Mantua 2009), and is also the period when adult murres are returning to breeding colonies in Washington (Zador et al. 2009). The summer period captures the entirety of the murre breeding period on Tatoosh (Zador et al. 2009).

Monthly mean sea surface temperature (SST) was obtained from the Amphitrite Point $\left(48^{\circ} 55.2^{\prime} \mathrm{N}\right.$, $125^{\circ} 32.7^{\prime} \mathrm{W}$ ) lighthouse data series (Department of Fisheries and Oceans, Canada: www.pac.dfo-mpo. gc.ca). Monthly anomalies of the Coastal Upwelling Index (UI) at $48^{\circ} \mathrm{N}, 125^{\circ} \mathrm{W}$ were obtained from the 
Pacific Fisheries Environmental Laboratory (www. pfeg.noaa.gov). Both SST and UI were averaged into spring and summer bins.

To measure the onset of coastal upwelling, spring transition dates were calculated as the date when the daily upwelling indices and daily sea level residuals, low pass filtered with a stop frequency of 1/(10 days), transitioned from negative to positive (values from $\mathrm{E}$. A. Logerwell pers. comm. 2010, but see Logerwell et al. (2003) for details on methods). Holt \& Mantua 2009 showed that this method consistently provided a reliable indicator of the spring transition in the northern California Current.

Basin-wide physical forcing conditions were characterized by the Multivariate El Niño Index (MEI) and the Pacific Decadal Oscillation (PDO). Monthly MEI data were obtained from the National Oceanic and Atmospheric Administration's Earth System Research Laboratory (www.esrl.noaa.gov). Index values from September through August were averaged to create an MEI index that reflected the entire range of conditions experienced by adult murres from the end of a breeding season through the completion of the next. Monthly PDO data were obtained from the University of Washington's Joint Institute for the Study of the Atmosphere and Ocean (jisao.washington.edu/pdo/). We followed Mantua et al. (1997) in using cold season (November to March) values of the $\mathrm{PDO}$, for consistency in the description of the interdecadal fluctuations in the index.

All indices were normalized using the mean and standard deviation of the study period (1996 to 2009). The signs (+ or - ) of each index were standardized, so that the direction associated with conditions favorable to ocean productivity was always the same. This ensured that the indices could be interpreted together. All indices were then combined with a PCA to create summary variables that captured the overall annual environmental conditions.

\section{Statistical analyses}

For all variables summarized at the level of fishwatch, only watches with a minimum of 10 chicks were included, to ensure an adequate sample size. All statistical analyses were completed using either $\mathrm{R}$, version 2.10.1 (R Development Core Team 2005) or Microsoft Excel ${ }^{\circledR}$ 2007. PCAs of prey composition and environmental variables were completed using the $\mathrm{R}$ package 'vegan' (Oksanen et al. 2010). Where necessary, data were square-root transformed to eliminate bias on annual means. We used Student's t-tests and analysis of variance (ANOVA) to categorize annual foraging strategies based on provisioning rate, energy per fish and energy return rate to chicks. Principal components of prey composition were compared to measures of diet using linear regression. Multivariate analysis of variance (MANOVA) was used to compare foraging categories within the context of principal components of environmental indices.

\section{RESULTS}

From 1996 through 2009, 1178 fish-watches were conducted, during which a total of 1259 pairs returned 10493 prey items representing 29 taxonomic categories (see Supplement S4) to chicks of all ages. Sampling effort was variable across years, with minimums of $61 \mathrm{~h}$ (in 2006), and 358 identified fish (in 1996). As only $0.51 \%$ of the prey items returned in all years were non-fish taxa (crustaceans or cephalopods), prey items are hereafter referred to as 'fish'.

Pacific herring was the most abundant species overall (35\% of the diet), ranging between 17 and $66 \%$ by number annually (Fig. 1), and the only taxon achieving 'major' (>5\%) status in all years. Surf smelt ( $25 \%$ of the total diet) was almost as dominant as herring early in the time series, but was scarce $(<5 \%)$ after 2005 (Fig. 1). Despite the relative dominance of herring and surf smelt, prey diversity was high. Eight other fish taxa composed $>5 \%$ of the diet in at least 1 yr (Fig. 1). Among these secondary prey species, Pacific sandlance Ammodytes hexapterus and eulachon Thaleichthys pacificus together comprised a considerable percentage of the diet especially early in the series. However, sandlance essentially disappeared from the diet after 2002 (Fig. 1). Eulachon was more variable: absent in 2000 and a minimal diet component after 2004. Northern anchovy Engraulis mordax (2005) and whitebait smelt Allosmerus elongatus (2009) began appearing coincidently with the decline of sandlance, eulachon, and surf smelt (Fig. 1). Other major species groups, including all 4 multi-species categories, only reached $5 \%$ of the diet in a few years (Fig. 1), and never approached dominance.

The PCA of species composition resulted in 3 leading principal components (PC1, 2, and 3) of variability that together explained $85.3 \%$ of the variation. PC1 (44.5\% of total variation) primarily highlighted the appearance of whitebait smelt in 2009, contrasting it with all other years, in which surf smelt was the predominant smelt species returned. Beyond highlighting the uniqueness of this single year, however, 


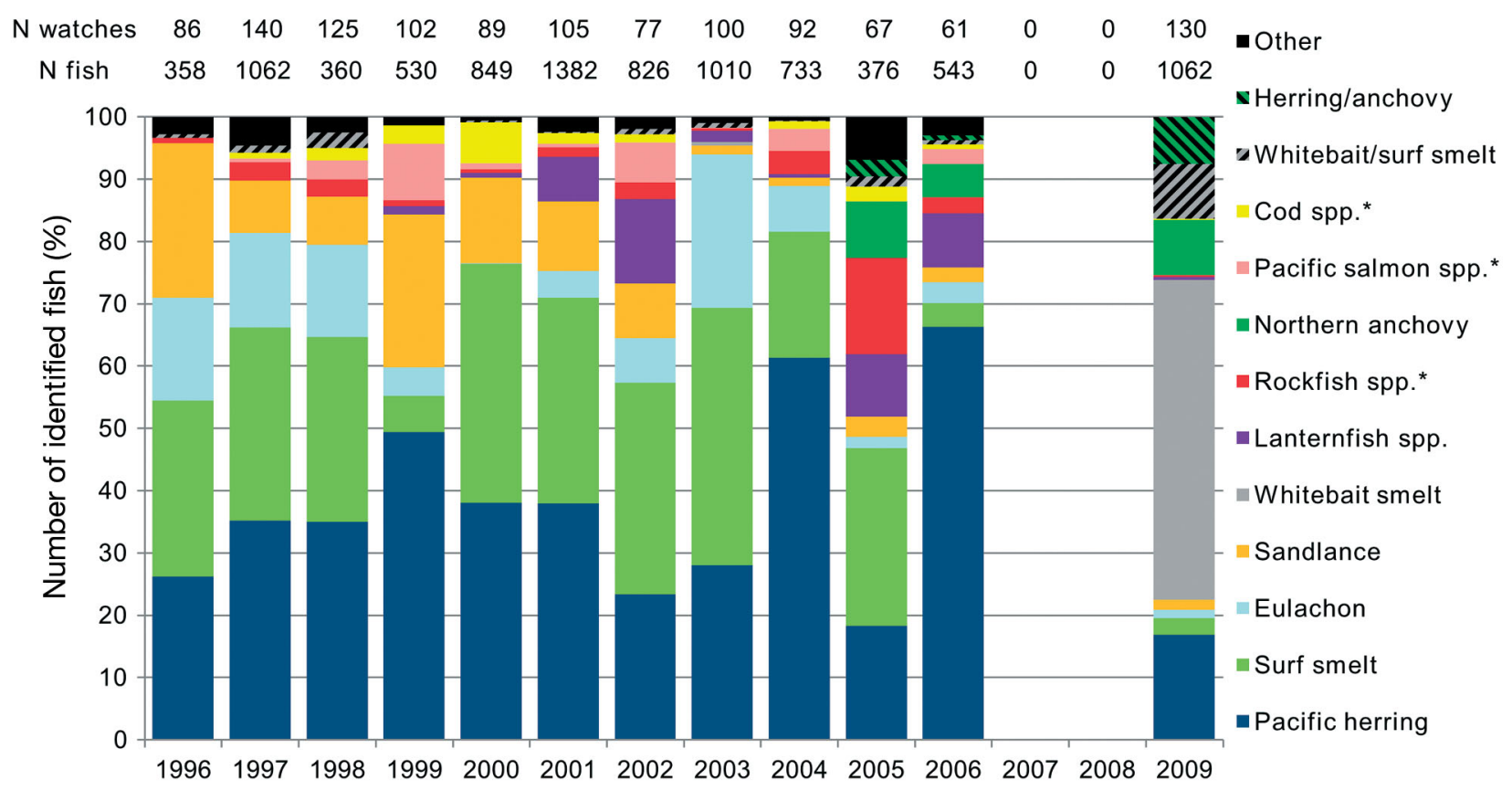

Fig. 1. Uria aalge. Annual percent composition of common murre chick diet by number of returned fish that could be identified. Non-major taxa ( $<5 \%$ of diet in each year) are combined into 'other'. Multi-species taxon groups are denoted by 'spp.' Asterisks ( ${ }^{*}$ ) indicate that all fish taken were juveniles. Hatched categories are cases in which fish could only be identified to a dual species category. Sample sizes for number of watches and number of fish identified (to chicks of all ages) are indicated above the graph. Prey are: Pacific herring Clupea harengus pallasi, surf smelt Hypomesus pretiosus, whitebait smelt Allosmerus elongatus, eulachon Thaleichthys pacificus, Pacific sandlance Ammodytes hexapterus, lanternfish spp. (Family: Myctophidae), rockfish Sebastes spp., northern anchovy Engraulis mordax, Pacific salmon spp. (Family: Salmonidae), cod spp. (Family: Gadidae)

this axis did not provide considerable information about larger patterns. PC2 (29.2\% of total variation) differentiated years in which Pacific herring was dominant (e.g. 1999, 2004, 2006) vs. relatively minimal (e.g. 2003, 2005, 2009), and suggests a replacement by smelt (either surf or whitebait) in the latter condition. PC3 $(11.6 \%$ of total variation) resolved patterns in some of the less prominent diet groups, particularly differentiating reliance on anchovy, lanternfish, and rockfish (e.g. 2002, 2004 to 2006) from reliance on eulachon and sandlance (e.g. 1996, 1999, and 2003). Much of the variation in diet composition can therefore be explained by the relative presence of Pacific herring and various smelt species. Biplots and complete loadings for all years and species are included in Supplement S6.

The quality (i.e. total energy content) of a chick meal depended largely on the size range over which common species were returned (Fig. 2). Murres returned Pacific herring over a wider length range than any other prey category (Fig. 2, Line a), and large herring were the highest energy content meals that murre chicks received. By contrast, small her- ring provided relatively less energy than most other fish of comparable sizes, especially lanternfish and rockfish (Fig. 2, Lines $\mathrm{f}$ and $\mathrm{g}$, respectively), which were only returned at small sizes, but were very energy rich. Eulachon had the highest energy content of all commonly returned species between approximately 100 and $130 \mathrm{~mm}$ total length (Fig. 2, Line c).

Annual averages of energy (KJ) per fish varied dramatically between years with a 6 yr run (1999 to 2004) of higher than average quality (although not always significantly so; Table 1) flanked by years of average or below average quality (Fig. 3A; see Supplement S5 for non-normalized values). Average annual provisioning rate ranged from a low of 0.13 fish chick ${ }^{-1} \mathrm{~h}^{-1}$ (or $7.5 \mathrm{~h}$ between meals) in 1998 to a high of 0.31 fish chick $^{-1} \mathrm{~h}^{-1}$ (or $3.2 \mathrm{~h}$ between meals) in 2009. Together with average energy return rate (KJ chick ${ }^{-1} \mathrm{~h}^{-1}$; Fig. 3B), these variables were used to categorize years from a chick's perspective. Years with lower than average energy return rate (1997, 1998, and 2005) were termed 'poor', and those with higher than average energy return rate $(2000$ 
through 2004) were termed 'good'. Years with moderate energy return rate resulting from below average prey quality but above average provisioning rate

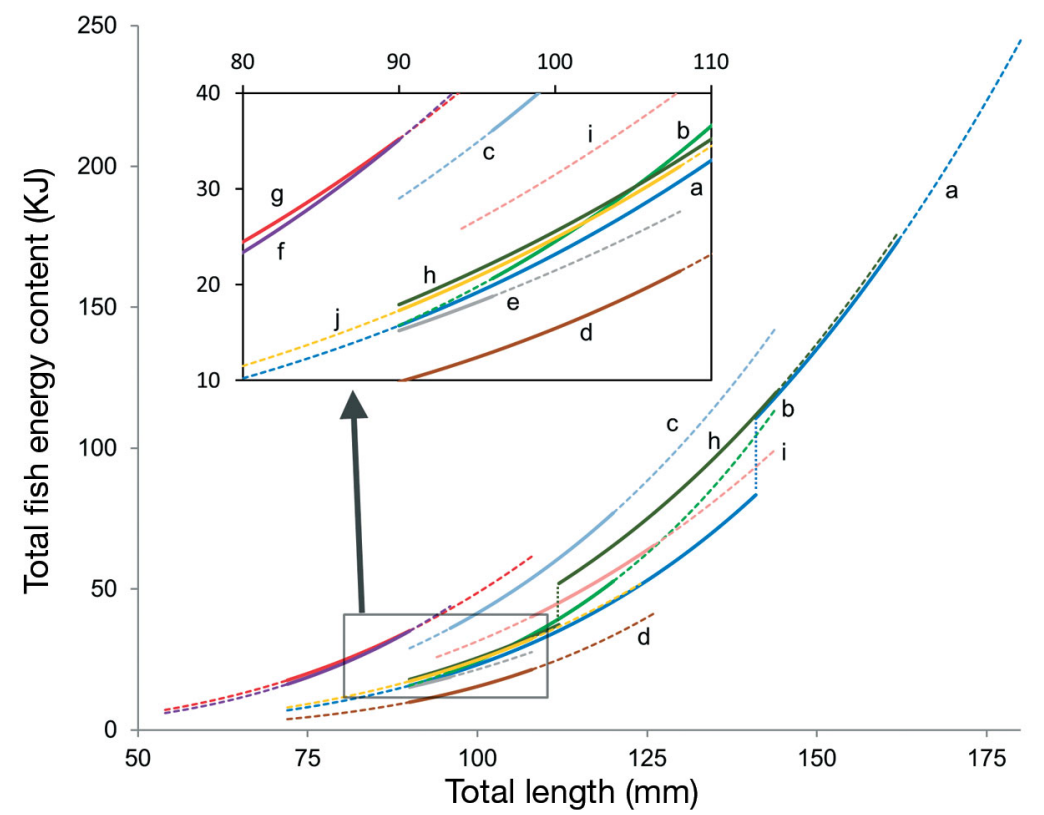

Fig. 2. Uria aalge. Estimated total energy content (KJ) of individual fish at lengths at which adult murres returned them. Curve limits (dashed lines) indicate the 5 to 95 percentiles, and solid curve portions indicate the 25 to 75 percentiles of the size range of each species category returned to murres in this study. Species categories are: (a) Pacific herring Clupea harengus pallasi, (b) surf smelt Hypomesus pretiosus, (c) eulachon Thaleichthys pacificus, (d) Pacific sandlance Ammodytes hexapterus, (e) whitebait smelt Allosmerus elongatus, (f) lanternfish (Family: Myctophidae), (g) rockfish Sebastes spp., (h) northern anchovy Engraulis mordax, (i) Pacific salmon (Family: Salmonidae), and (j) cod (Family: Gadidae). Dotted breaks in curves (a) and (h) indicate age 0 to age 1 size category breaks for herring and anchovy, respectively
(2006 and 2009) were termed 'compensation', suggesting a shift in strategy by adults. This provisioning strategy resulted in a small decrease in energy return rates, but was clearly better from a chick's perspective than 'poor' years (Fig. 3B). The remaining years in the data series (1996 and 1999) displayed average energy return rates, but no clearly dichotomous signal in prey quality and provisioning rate, and were therefore considered transitional.

Across all years, low average energy per fish was closely correlated with smaller average fish lengths (Pearson's $r=0.943$, df $=10, p<0.001$ ), but the effect of smaller fish was most pronounced during years in the 'compensation' category (2006 and 2009). Decreases in prey quality coincided with dramatic dominance by single prey species in those years; Pacific herring in 2006 and whitebait smelt in 2009 (Fig. 1). Whitebait smelt in 2009 were significantly smaller than all the surf smelt returned in all years $\left(t_{1997}=25.7 ; \mathrm{p}<\right.$ 0.001), and herring in 2006 were significantly smaller than the herring returned in all other years $\left(t_{329}=14.7 ; \mathrm{p}<0.001\right)$.

Average energy per fish was not correlated with the 2 principal components of prey composition that provided useful interpretations: PC2 (Pearson's $r=0.042$, df $=10, \mathrm{p}=0.897$ ) or PC3 (Pearson's $\mathrm{r}=$

Table 1. Uria aalge. Comparison of energy return rate, energy per fish and provisioning rate between each year and the average value for all years of the study, with Student's $t$-test statistics, associated p-values (bold indicates statistical significance, $\mathrm{p}<0.05$ ), and directions of the relationship. The sample size (n) of fish-watches was constrained in each year to those for which there were $\geq 10$ chicks older than 1 wk present on the plot

\begin{tabular}{|c|c|c|c|c|c|c|c|c|c|c|}
\hline \multirow[t]{2}{*}{ Year } & \multirow[t]{2}{*}{$\mathrm{n}$} & \multicolumn{3}{|c|}{$\begin{array}{c}\text { Energy return rate - } \\
\left(\mathrm{KJ} \text { chick }^{-1} \mathrm{~h}^{-1}\right)\end{array}$} & \multicolumn{3}{|c|}{$\underset{(\mathrm{KJ})}{\text { Energy per fish }}$} & \multicolumn{3}{|c|}{$\begin{array}{c}\text { Provisioning rate } \\
\left(\text { fish } \text { chick }^{-1}\right)\end{array}$} \\
\hline & & $t$ & $\mathrm{p}$ & $+/-$ & $t$ & $\mathrm{p}$ & $+/-$ & $t$ & $\mathrm{p}$ & $+/-$ \\
\hline 1996 & 65 & -1.193 & 0.237 & - & 0.728 & 0.470 & + & -3.323 & 0.002 & - \\
\hline 1997 & 119 & -8.272 & $<0.001$ & - & -9.599 & $<0.001$ & - & -2.941 & 0.004 & - \\
\hline 1998 & 100 & -7.185 & $<0.001$ & - & -0.662 & 0.509 & - & -8.495 & $<0.001$ & - \\
\hline 1999 & 74 & 1.164 & 0.248 & + & 1.490 & 0.140 & + & -0.248 & 0.805 & - \\
\hline 2000 & 75 & 2.346 & 0.022 & + & 1.341 & 0.184 & + & 1.842 & 0.070 & + \\
\hline 2001 & 105 & 3.385 & 0.001 & + & 3.191 & 0.002 & + & 1.364 & 0.176 & + \\
\hline 2002 & 76 & 3.971 & $<0.001$ & + & 4.735 & $<0.001$ & + & 1.250 & 0.215 & + \\
\hline 2003 & 90 & 3.765 & $<0.001$ & + & 5.544 & $<0.001$ & + & 0.744 & 0.459 & + \\
\hline 2004 & 92 & 4.107 & $<0.001$ & + & 4.627 & $<0.001$ & + & 1.330 & 0.187 & + \\
\hline 2005 & 60 & -2.234 & 0.029 & - & -0.480 & 0.633 & - & -1.701 & 0.094 & - \\
\hline 2006 & 59 & 0.017 & 0.987 & + & -4.429 & $<0.001$ & - & 3.770 & $<0.001$ & + \\
\hline 2009 & 96 & -0.852 & 0.397 & - & -12.580 & $<0.001$ & - & 8.010 & $<0.001$ & + \\
\hline
\end{tabular}




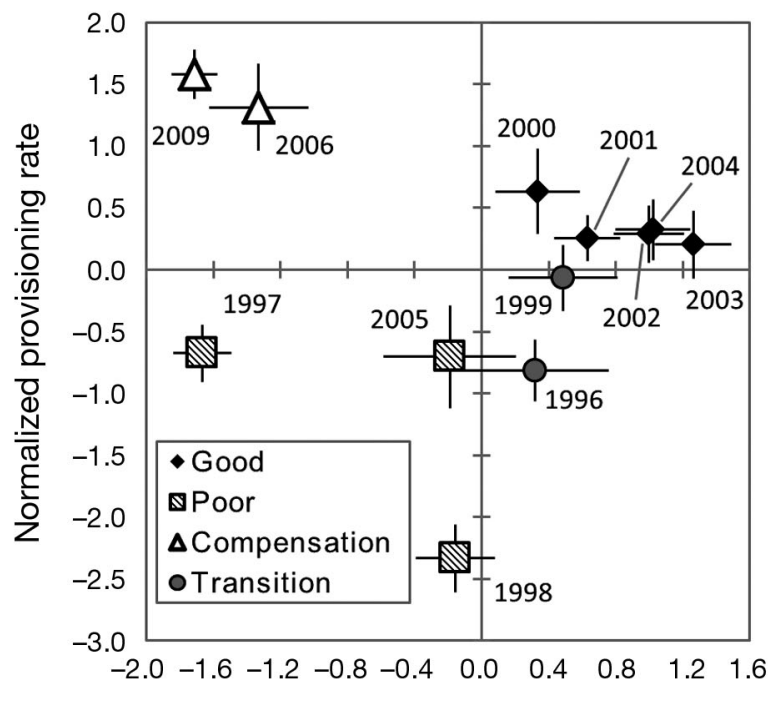

A

Normalized energy per fish
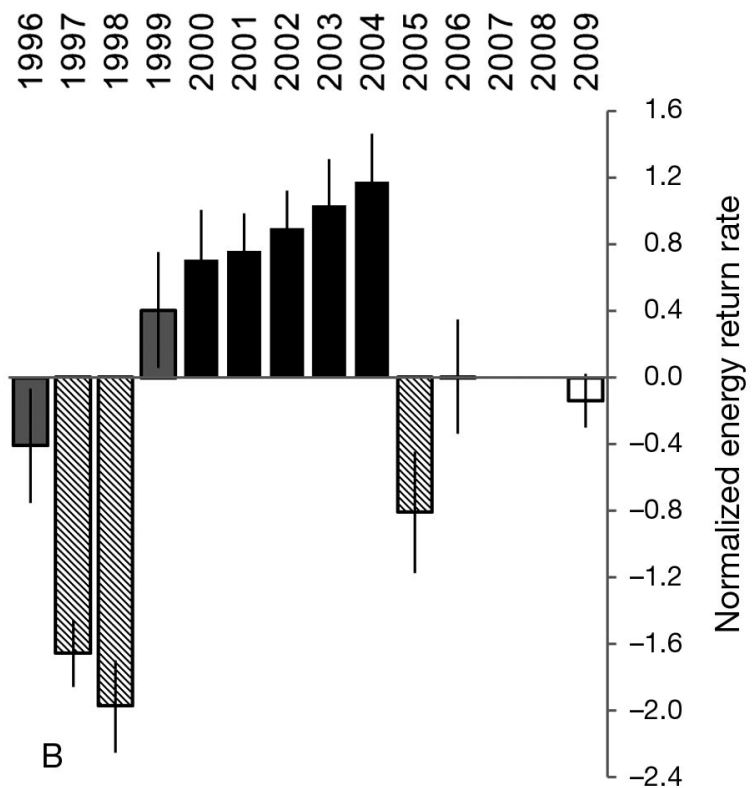

Fig. 3. Uria aalge. Annual averages of (A) energy (KJ) per fish plotted against provisioning rate (fish $\left.\mathrm{chick}^{-1} \mathrm{~h}^{-1}\right)$, and $(\mathrm{B})$ energy return rate $\left(\mathrm{KJ} \mathrm{Chick}^{-1} \mathrm{~h}^{-1}\right)$; both calculated from returns to chicks older than $1 \mathrm{wk}$. All 3 variables have been square-root transformed and then normalized using the mean and standard deviation across all years. Error bars are $1 \mathrm{SE}$, also normalized by dividing by the standard deviation across all years. Years are grouped by diet categories: poor, good, and compensation; with the 2 transition years that could not be conclusively categorized depicted as well

0.092, $\mathrm{df}=10, \mathrm{p}=0.777$ ). Interannual patterns in provisioning rate (fish chick ${ }^{-1} \mathrm{~h}^{-1}$ ) were also not correlated with prey diversity (PC2: Pearson's $\mathrm{r}=0.068$, $\mathrm{df}=10, \mathrm{p}=0.835 ;$ PC3: Pearson's $\mathrm{r}=-0.221, \mathrm{df}=10$, $\mathrm{p}=0.490)$.

The 3 leading principal components from the PCA of environmental indices cumulatively described $85.4 \%$ of the variation (see Supplement S7 for biplots and PC scores for all years and variables). Unsurprisingly, PC1 $(47.8 \%$ of the variation) primarily described years as generally favorable (cool, early spring transition, strong upwelling) or unfavorable (warm, late spring transition, weak upwelling). The contribution of local vs. basin-wide scale forcing was captured by PC2 (19.4\% of the variation), while differences in spring vs. summer forcing were captured by PC3 (18.2\% of the variation). Years were grouped using the categories (poor, good, and compensation) identified from the murre chick diet analysis, and compared in the context of each component of oceanographic forcing (Fig. 4). None of the diet categories showed significantly different average component scores (MANOVA: Wilks' $\lambda=0.396, F_{6,10}=$ $0.981, \mathrm{p}=0.485)$; however, the ocean conditions as indicated by PC1 were generally unfavorable during 'poor' diet years (Fig. 4).

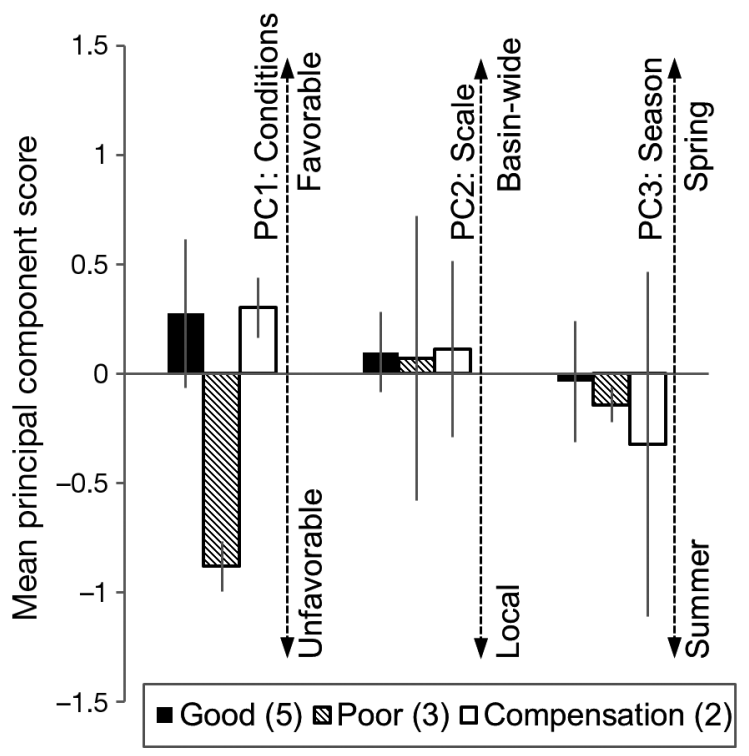

Fig. 4. The state of physical forcing signals in years categorized as either poor $(1997,1998,2005)$, good (2000 to 2004), or compensation $(2006,2009)$. Bars represent average ( $\pm 1 \mathrm{SE}$ ) principal component $(\mathrm{PC})$ scores in each category. The interpretation for each PC axis is indicated to the right of the bars for that axis (see Supplement S4 at www.int-res. com/articles/suppl/m460p247_supp.xls for details on PCA). Sample sizes follow the name of each category 


\section{DISCUSSION}

This study provides evidence that in a prey species-rich system, common murres can adopt different provisioning strategies depending on the nature of the available prey. Disarticulating annual energy return rate to chicks into measures of meal quality (energy per fish) and meal quantity (delivery rate: fish chick $^{-1} \mathrm{~h}^{-1}$ ), allowed us to distinguish periods when foraging was regulated by either parental behavior and/or environmental limitation. Specifically, we found a period during which adult murres used a strategy that compensated for low quality prey by increasing delivery rate, contrasted against years in which low provisioning rate and low meal quality resulted in low energy return rates.

Tatoosh Island murres significantly increased provisioning rates in 2006 and 2009 when prey quality (energy per meal) was low (Fig. 3) due to the small size of Pacific herring and whitebait smelt, respectively. Davoren \& Montevecchi (2003) reported a decline in murre prey quality as a consequence of the decline in the size of locally available capelin. Other studies found that adult murres spent less time coattending their chicks, and therefore more time foraging, when prey quantity (Burger \& Piatt 1990, Zador \& Piatt 1999, Harding et al. 2007) or quality (Wanless et al. 2005) was low. Chinstrap penguins Pygoscelis antarctica made deeper foraging dives to shift from targeting krill Euphausia superba to fish when the size of krill decreased (Miller \& Trivelpiece 2008). Kitaysky et al. (2000) demonstrated that foraging effort (i.e. field metabolic rate) can be higher when food availability declines for some seabird species, but not others. Without data on adult energy expenditure, we cannot say with certainty that foraging effort among Tatoosh murres during 2006 and 2009 was higher than in other years. However, energy return rates were lower in these years than in 'good' years (Fig. 3B), suggesting that murres reached limits in their ability to effectively provision chicks with this strategy. A likely, albeit speculative, cause for this limitation is that their ability to find larger, more suitable prey was reduced.

An alternative possibility for the quick return of small fish during 'compensation' years is that those fish were super-abundant close to the colony, making it a better strategy from an adult's perspective. Information on prey distribution around the colony is very limited, but Parrish et al. (1998) found that prior to our study period the highest prey densities were very close $(<5 \mathrm{~km})$ to the island and that foraging murres concentrated in that area. Whitebait smelt have also been a major component of the forage fish community along the Washington Coast for much of our study period (Brodeur et al. 2005). The sudden reliance on whitebait smelt in 2009, therefore, suggests that higher quality fish in the immediate area were scarce enough to warrant a shift to this lowquality species.

Changes in the species composition of chick diet can have negative consequences, for example in California, where rhinoceros auklet Cerorhinca monocerata chick growth rate was lower in years dominated by Pacific saury Cololabis saira vs. northern anchovy (Thayer \& Sydeman 2007). The replacement of a high quality prey in a system by one of lower energy content, to the detriment of predators, has been labeled the junk food hypothesis (Österblom et al. 2008). As originally conceived, this hypothesis suggested that a community shift from high-lipid to low-lipid prey (Anderson \& Piatt 1999) could result in lower body condition of offspring (Rosen \& Trites 2005) following a shift in adult diet (Trites et al. 2007). Reliance on 'junk food' negatively affected common murres when anchovy replaced juvenile rockfish as the predominant prey species in the diet of Southeast Farallon Island chicks (Sydeman et al. 2001). Even a preferred prey species could be considered 'junk food,' if it can only be found at smaller sizes (e.g. Davoren \& Montevecchi 2003) or has decreased energy density (e.g. Wanless et al. 2005) at a given time. During 2006 and 2009 on Tatoosh, low-quality prey in the diet, coupled with the slightly lower energy return rates, suggests that reliance on 'junk food' was the best strategy available.

Suryan et al. (2002) suggested that interannual variation in environmental forcing creates a threshold, above which parental behavior can flexibly accommodate shifts in the prey landscape. Fine scale adjustments of prey choice and provisioning rate in 'good' years (2000 to 2004) may be evidence of parental regulation in Tatoosh murres. These years had the highest energy return rates and were characterized by moderate meal delivery rates, in keeping with Cairns' (1987) hypothesis that when there is a sufficient quantity of high-quality prey, birds do not forage more than is necessary. Chicks can also reach physical limits in consumption rate (Harris \& Wanless 1985 ) and the size and shape of fish they can ingest (Atwood \& Kelly 1984, Harris et al. 2007), leading to upper bounds on the energy per fish and provisioning rate during years with plentiful food.

Below average energy return rates occurred in years in which ocean conditions were unfavorable to productivity (Fig. 3). The lack of any relationship to 
temporal or spatial scale differences in oceanographic forcing is likely due to different causes for the unfavorable conditions in these 3 years (1997, 1998, and 2005). A strong El Niño in 1997 to 1998 resulted in high sea surface temperatures and low productivity throughout the California Current system (Lynn et al. 1998, Chavez et al. 2002). In 2005, an abnormally late spring transition to upwelling conditions caused severely reduced primary productivity (Barth et al. 2007), which resulted in breeding failures in marbled murrelets Brachyramphus marmoratus in British Columbia (Ronconi \& Burger 2008) and nest abandonment in Cassin's auklets Ptychoramphus aleuticus throughout the California Current (Sydeman et al. 2006). We suggest that these oceanographic events may have decreased overall prey abundance in the environment around Tatoosh Island during these years. Low prey abundance, or at least a lack of high quality prey, could have resulted in decreases in provisioning rate due to increased search times (Ronconi \& Burger 2008) and/or more time spent self-provisioning by the adults (Weimerskirch et al. 2003, Welcker et al. 2009a). Universally low prey abundance would explain why a strategy of returning many small fish (i.e. 'compensation') was not available.

The 2 transitional years (1996 and 1999) immediately adjacent to the 2 poorest diet years in our study (the 1997 to $1998 \mathrm{El}$ Niño) may have been the result of gradual ecosystem change. Mackas et al. (2007) found a gradual shift in the zooplankton community off Vancouver Island to 'southern' species that began in 1995 and continued through the end of the 1997 to 1998 El Niño. A similar gradual shift in the fish community began during the strong La Niña event of 1999 (Emmett et al. 2006).

Wells et al. (2008) found that the integration of several physical parameters, both atmospheric and oceanic, could be related directly and indirectly (that is, through trophic pathways) to seabird production, including murres, in the California Current System. In a study comparing oceanographic forcing to the proportion of rockfish in murre chick diets in California, Miller \& Sydeman (2004) found that strong forcing events could be linked to some annual diet shifts, but the more subtle effects of PDO regime shifts were only apparent in an analysis of seasonal trends. Definite causal relationships between murre chick diet and bottom-up forcing may be apparent when smaller time and space scales are examined, such as the link between 3 to $5 \mathrm{~d}$ upwelling events and lanternfish appearance in Tatoosh Island murre chick diets reported by Parrish \& Zador (2003). The dramatic changes in murre diet described in our study during 2006 and 2009 suggest that murres respond to environmental changes that the traditional physical forcing indices are not able to distinguish.

Changes in prey are rarely the only environmental limitation that organisms face. The reproductive success of murres on Tatoosh is also forced by top-down effects from bald eagles Haliaeetus leucocephalus (Parrish et al. 2001) and peregrine falcons Falco peregrinus (Paine et al. 1990). This forcing was likely the primary cause of the breeding failures in 2007 and 2008 (J. K. Parrish unpubl. obs.), but the low quality diet in recent years raises the possibility that an interaction between top-down and bottom-up effects may make breeding difficult for these birds in the future. More local scale studies on prey abundance and distribution in specific predator habitats would be helpful in determining what kinds of changes in the prey base are occurring.

Persistent, local declines of high-energy prey may put predator populations at risk (Pichegru et al. 2010). Both common murres and closely related thick-billed murres Uria lomvia, like many other long-lived seabirds, are highly philopatric (Ainley et al. 2002, Steiner \& Gaston 2005), and may be reluctant to abandon a colony if conditions deteriorate. Organisms that can effectively buffer the effects of low prey quality by increasing the quantity consumed may be able to overcome the mobility limitations imposed on central-place foragers (Cruz-Rivera \& Hay 2000), but alternative strategies have limits to their effectiveness. For Tatoosh murres, prey species identity, richness, and size shifted dramatically after 2004 (albeit with no data from 2007 and 2008; Fig. 1), accompanied soon afterwards by a shift in foraging strategy. If 'compensation' years such as 2006 and 2009 are indicative of a trend, seabirds in the region may be experiencing a relatively new and fairly impoverished environmental state, regardless of the relative influence of bottom-up forcing.

Variation in prey selectivity and compensatory foraging strategies have been described in seabirds at both the individual (Elliott et al. 2009) and colony (Miller \& Trivelpiece 2008) level. Birds can also use different strategies during different stages of the chick-rearing cycle (Deagle et al. 2008). Adaptability in foraging strategy is also evident in other marine organisms, such as sharks (Lucifora et al. 2006, Baremore et al. 2008) and marine mammals (Boyd et al. 1994, Skern-Mauritzen et al. 2009, Arnould et al. 2011). If diverse marine ecosystems such as the northern California Current are undergoing a gradual shift in the prey base, it will be crucial to monitor 
not only the population levels of predators in the system, but also the ability of predators to buffer those changes through behavioral flexibility.

Acknowledgements. We thank the Makah Indian Nation for granting us access to Tatoosh Island, and G. L. Hunt Jr., N. Mantua, and E. Runnells for contributions in manuscript preparation. Three anonymous reviewers provided very helpful feedback. We also acknowledge the efforts of K. Haapa-aho, who provided guidance on caloric analysis. Special thanks are due to all those who collected both data on Tatoosh Island murres and the prey items used in the calculation of energy density, especially J. Dolliver, N. Hamel, C. French, P. Hodum, and T. Good. This paper is a result of research funded in part by Washington Sea Grant, the Tenyo Maru Trustees Council, the National Oceanic and Atmospheric Administration Coastal Ocean Program, the SeaDoc Society, Washington Department of Fish and Wildlife, and the University of Washington, School of Aquatic and Fishery Sciences.

\section{LITERATURE CITED}

Ainley DG, Spear LB, Allen SG (1996) Variation in the diet of Cassin's auklet reveals spatial, seasonal, and decadal occurrence patterns of euphausiids off California, USA. Mar Ecol Prog Ser 137:1-10

Ainley DG, Nettleship DN, Carter HR, Storey AE (2002) Common murre (Uria aalge). In: Poole A (ed) The birds of North America online. Cornell Lab of Ornithology, Ithaca, NY http://bna.birds.cornell.edu/bna/species/666

Anderson PJ, Piatt JF (1999) Community reorganization in the Gulf of Alaska following ocean climate regime shift. Mar Ecol Prog Ser 189:117-123

Anthony JA, Roby DD, Turco KR (2000) Lipid content and energy density of forage fishes from the northern Gulf of Alaska. J Exp Mar Biol Ecol 248:53-78

Arnould JPY, Cherel Y, Gibbens J, White JG, Littnan CL (2011) Stable isotopes reveal inter-annual and interindividual variation in the diet of female Australian fur seals. Mar Ecol Prog Ser 422:291-302

Ashmole NP (1971) Seabird ecology and the marine environment. In: Farner DS, King JR (eds) Avian biology, Vol 1. Academic Press, New York, NY, p 224-286

Atwood JL, Kelly PR (1984) Fish dropped on breeding colonies as indicators of least tern food habits. Wilson Bull 96:34-47

Baremore IE, Murie DJ, Carlson JK (2008) Prey selection by the Atlantic angel shark Squatina dumeril in the northeastern Gulf of Mexico. Bull Mar Sci 82:297-313

Barth JA, Menge BA, Lubchenco J, Chan F and others (2007) Delayed upwelling alters nearshore coastal ocean ecosystems in the northern California Current. Proc Natl Acad Sci USA 104:3719-3724

> Bertram DF, Welham CVJ, Ydenberg RC (1996) Flexible effort in breeding seabirds: Adjustment of provisioning according to nestling age and mass. Can J Zool 74: 1876-1881

Boyd IL, Arnould JPY, Barton T, Croxall JP (1994) Foraging behavior of Antarctic fur seals during periods of contrasting prey abundance. J Anim Ecol 63:703-713

Brodeur RD, Fisher JP, Emmett RL, Morgan CA, Casillas E
(2005) Species composition and community structure of pelagic nekton off Oregon and Washington under variable oceanographic conditions. Mar Ecol Prog Ser 298: 41-57

> Bryant R, Jones IL, Hipfner JM (1999) Responses to changes in prey availability by common murres and thick-billed murres at the Gannet Islands, Labrador. Can J Zool 77 : 1278-1287

Burger AE, Piatt JF (1990) Flexible time budgets in breeding common murres: buffers against variable prey abundance. Stud Avian Biol 14:71-83

> Burke CM, Montevecchi WA (2009) The foraging decisions of a central place foraging seabird in response to fluctuations in local prey conditions. J Zool (Lond) 278:354-361

Cairns DK (1987) Seabirds as indicators of marine food supplies. Biol Oceanogr 5:261-272

> Chaurand T, Weimerskirch H (1994) The regular alternation of short and long foraging trips in the blue petrel Halobaena caerulea: a previously undescribed strategy of food provisioning in a pelagic seabird. J Anim Ecol 63: 275-282

> Chavez FP, Pennington JT, Castro CG, Ryan JP and others (2002) Biological and chemical consequences of the 1997-1998 El Niño in central California waters. Prog Oceanogr 54:205-232

Cruz-Rivera E, Hay ME (2000) Can quantity replace quality? Food choice, compensatory feeding, and fitness of marine mesograzers. Ecology 81:201-219

Davoren GK, Montevecchi WA (2003) Signals from seabirds indicate changing biology of capelin stocks. Mar Ecol Prog Ser 258:253-261

Deagle BE, Gales NJ, Hindell MA (2008) Variability in foraging behaviour of chick-rearing macaroni penguins Eudyptes chrysolophus and its relation to diet. Mar Ecol Prog Ser 359:295-309

Elliott KH, Davoren GK, Gaston AJ (2008a) Sources of bias in observations of murre provisioning behavior. J Field Ornithol 79:298-307

Elliott KH, Woo K, Gaston AJ, Benvenuti S, Dall'Antonia L, Davoren GK (2008b) Seabird foraging behaviour indicates prey type. Mar Ecol Prog Ser 354:289-303

Elliott KH, Woo KJ, Gaston AJ (2009) Specialization in murres: the story of eight specialists. Waterbirds 32:491-506

Emmett RL, Krutzikowsky GK, Bentley P (2006) Abundance and distribution of pelagic piscivorous fishes in the Columbia River plume during spring/early summer 1998-2003: relationship to oceanographic conditions, forage fishes, and juvenile salmonids. Prog Oceanogr 68: $1-26$

$>$ Foy RJ, Paul AJ (1999) Winter feeding and changes in somatic energy content of age-0 Pacific herring in Prince William Sound, Alaska. Trans Am Fish Soc 128:1193-1200

Froese F, Pauly D (2010) FishBase. www.fishbase.org (accessed 24 Jan 2010)

Gaston AJ, Woo K, Hipfner JM (2003) Trends in forage fish populations in northern Hudson Bay since 1981, as determined from the diet of nestling thick-billed murres Uria lomvia. Arctic 56:227-233

Harding AMA, Piatt JF, Schmutz JA, Shultz MT, Pelt TIV, Kettle AB, Speckman SG (2007) Prey density and the behavioral flexibility of a marine predator: the common murre (Uria aalge). Ecology 88:2024-2033

> Harris MP, Wanless S (1985) Fish fed to young guillemots, Uria aalge, and used in display on the Isle of May, Scotland. J Zool 207:441-458 
Harris MP, Beare D, Toresen R, Nottestad L and others (2007) A major increase in snake pipefish (Entelurus aequoreus) in northern European seas since 2003: potential implications for seabird breeding success. Mar Biol 151:973-983

Hart JL (1973) Pacific fishes of Canada. Fish Res Board Can Bull 180

> Haynes EB, Wigley RL (1969) Biology of northern shrimp Pandalus borealis in Gulf of Maine. Trans Am Fish Soc 98:60-76

Hickey BM (1998) Coastal oceanography of western North America from the tip of Baja California to Vancouver Island. In: Robinson AR, Brink KH (eds) The sea, Vol 11. Wiley and Sons, New York, NY, p 345-393

> Hickey BM, Banas NS (2003) Oceanography of the US Pacific Northwest coastal ocean and estuaries with application to coastal ecology. Estuaries 26:1010-1031

- Hipfner JM (2009) Euphausiids in the diet of a North Pacific seabird: annual and seasonal variation and the role of ocean climate. Mar Ecol Prog Ser 390:277-289

Hipfner JM, Gaston AJ, Smith BD (2006) Regulation of provisioning rate in the thick-billed murre (Uria lomvia). Can J Zool 84:931-938

Holt CA, Mantua N (2009) Defining spring transition: regional indices for the California Current System. Mar Ecol Prog Ser 393:285-299

$>$ Hunt GL, Drew GS, Jahncke J, Piatt JF (2005) Prey consumption and energy transfer by marine birds in the Gulf of Alaska. Deep-Sea Res II 52:781-797

> Jodice PGR, Roby DD, Suryan RM, Irons DB and others (2006) Increased energy expenditure by a seabird in response to higher food abundance. Mar Ecol Prog Ser 306:283-293

Kitaysky AS, Hunt GL Jr., Flint EN, Rubega MA, Decker MB (2000) Resource allocation in breeding seabirds: responses to fluctuations in their food supply. Mar Ecol Prog Ser 206:283-296

Lack D (1968) Ecological adaptations for breeding in birds. Methuen, London

Lewis S, Sherratt TN, Hamer KC, Harris MP, Wanless S (2003) Contrasting diet quality of northern gannets Morus bassanus at two colonies. Ardea 91:167-176

Litz MNC, Heppell SS, Emmett RL, Brodeur RD (2008) Ecology and distribution of the northern subpopulation of northern anchovy (Engraulis mordax) off the U.S. West Coast. Calif Coop Ocean Fish Invest Rep 49:167-182

Logerwell EA, Mantua N, Lawson PW, Francis RC, Agostini VN (2003) Tracking environmental processes in the coastal zone for understanding and predicting Oregon coho (Oncorhynchus kisutch) marine survival. Fish Oceanogr 12:554-568

Lucifora LO, García VB, Menni RC, Escalante AH (2006) Food habits, selectivity, and foraging modes of the school shark Galeorhinus galeus. Mar Ecol Prog Ser 315: 259-270

Lynn RJ, Baumgartner T, Garcia J, Collins CA and others (1998) The state of the California Current, 1997-1998: transition to El Niño conditions. Calif Coop Ocean Fish Invest Rep 39:25-49

> Mackas DL, Peterson WT, Zamon JE (2004) Comparisons of interannual biomass anomalies of zooplankton communities along the continental margins of British Columbia and Oregon. Deep-Sea Res II 51:875-896

Mackas DL, Batten S, Trudel M (2007) Effects on zooplankton of a warmer ocean: recent evidence from the North- east Pacific. Prog Oceanogr 75:223-252

Mantua NJ, Hare SR, Zhang Y, Wallace JM, Francis RC (1997) A Pacific interdecadal climate oscillation with impacts on salmon production. Bull Am Meteorol Soc 78: 1069-1079

McCune B, Grace JB (2002) Analysis of ecological communities. MjM Software Design, Gleneden Beach, OR

McGowan JA, Cayan DR, Dorman LM (1998) Climate-ocean variability and ecosystem response in the Northeast Pacific. Science 281:210-217

Miller AK, Sydeman WJ (2004) Rockfish response to lowfrequency ocean climate change as revealed by the diet of a marine bird over multiple time scales. Mar Ecol Prog Ser 281:207-216

> Miller AK, Trivelpiece WZ (2008) Chinstrap penguins alter foraging and diving behavior in response to the size of their principle prey, Antarctic krill. Mar Biol 154:201-208

Oksanen J, Blanchet FG, Kindt R, Legendre P and others (2010) vegan: community ecology package. R package version 1.17-2. CRAN.R-project.org/package=vegan

Österblom H, Olsson O, Blenckner T, Furness RW (2008) Junk-food in marine ecosystems. Oikos 117:967-977

Paine RT, Wootton JT, Boersma PD (1990) Direct and indirect effects of peregrine falcon predation on seabird abundance. Auk 107:1-9

Paiva VH, Ramos JA, Catry T, Pedro P, Medeiros R, Palma J (2006) Influence of environmental factors and energetic value of food on little tern Sterna albifrons chick growth and food delivery. Bird Study 53:1-11

Parrish JK, Zador SG (2003) Seabirds as indicators: an exploratory analysis of physical forcing in the Pacific Northwest coastal environment. Estuaries 26:1044-1057

- Parrish JK, Lemberg N, South-Oryshchyn L (1998) Effects of colony location and nekton abundance on the at-sea distribution of four seabird species. Fish Oceanogr 7 : 126-135

> Parrish JK, Marvier M, Paine RT (2001) Direct and indirect effects: interactions between bald eagles and common murres. Ecol Appl 11:1858-1869

Piatt JF, Harding AMA, Shultz M, Speckman SG, van Pelt TI, Drew GS, Kettle AB (2007) Seabirds as indicators of marine food supplies: Cairns revisited. Mar Ecol Prog Ser 352:221-234

Pichegru L, Ryan PG, Crawford RJM, van der Lingen CD, Gremillet D (2010) Behavioural inertia places a top marine predator at risk from environmental change in the Benguela upwelling system. Mar Biol 157:537-544

R Development Core Team (2005) R: a language and environment for statistical computing. R Foundation for Statistical Computing, Vienna. www.r-project.org/

> Ronconi RA, Burger AE (2008) Limited foraging flexibility: increased foraging effort by a marine predator does not buffer against scarce prey. Mar Ecol Prog Ser 366: 245-258

$>$ Rosen DAS, Trites AW (2005) Examining the potential for nutritional stress in young Steller sea lions: physiological effects of prey composition. J Comp Physiol B 175: 265-273

Skern-Mauritzen M, Kirkman SP, Olsen E, Bjorge A and others (2009) Do inter-colony differences in Cape fur seal foraging behaviour reflect large-scale changes in the northern Benguela ecosystem? Afr J Mar Sci 31:399-408

Steiner UK, Gaston AJ (2005) Reproductive consequences of natal dispersal in a highly philopatric seabird. Behav Ecol 16:634-639 
Suryan RM, Irons DB, Kaufman M, Benson J, Jodice PGR, Roby DD, Brown ED (2002) Short-term fluctuations in forage fish availability and the effect on prey selection and brood-rearing in the black-legged kittiwake Rissa tridactyla. Mar Ecol Prog Ser 236:273-287

Sydeman WJ, Hester MM, Thayer JA, Gress F, Martin P, Buffa J (2001) Climate change, reproductive performance and diet composition of marine birds in the southern California Current system, 1969-1997. Prog Oceanogr 49:309-329

Sydeman WJ, Bradley RW, Warzybok P, Abraham CL and others (2006) Planktivorous auklet Ptychoramphus aleuticus responses to ocean climate, 2005: unusual atmospheric blocking? Geophys Res Lett 33, L22S09 doi: 10.1029/2006GL026736

Thaxter CB, Daunt F, Hamer KC, Watanuki Y and others (2009) Sex-specific food provisioning in a monomorphic seabird, the common guillemot Uria aalge: nest defence, foraging efficiency or parental effort? J Avian Biol 40: 75-84

Thayer JA, Sydeman WJ (2007) Spatio-temporal variability in prey harvest and reproductive ecology of a piscivorous seabird, Cerorhinca monocerata, in an upwelling system. Mar Ecol Prog Ser 329:253-265

Tirelli V, Borme D, Tulli F, Cigar M, Umani SF, Brandt SB (2006) Energy density of anchovy Engraulis encrasicolus L. in the Adriatic Sea. J Fish Biol 68:982-989

Trites AW, Calkins DG, Winship AJ (2007) Diets of Steller sea lions (Eumetopias jubatus) in Southeast Alaska, 1993-1999. Fish Bull 105:234-248

Van Pelt TI, Piatt JF, Lance BK, Roby DD (1997) Proximate composition and energy density of some North Pacific forage fishes. Comp Biochem Physiol A 118:1393-1398

Wanless S, Harris MP, Redman P, Speakman JR (2005) Low

Editorial responsibility: Rory Wilson,

Swansea, UK energy values of fish as a probable cause of a major seabird breeding failure in the North Sea. Mar Ecol Prog Ser 294:1-8

Ware DM, Thomson RE (2005) Bottom-up ecosystem trophic dynamics determine fish production in the Northeast Pacific. Science 308:1280-1284

- Weimerskirch H, Ancel A, Caloin M, Zahariev A, Spagiari J, Kersten M, Chastel O (2003) Foraging efficiency and adjustment of energy expenditure in a pelagic seabird provisioning its chick. J Anim Ecol 72:500-508

Welcker J, Harding AMA, Karnovsky NJ, Steen H, Strom H, Gabrielsen GW (2009a) Flexibility in the bimodal foraging strategy of a high Arctic alcid, the little auk Alle alle. J Avian Biol 40:388-399

> Welcker J, Harding AMA, Kitaysky AS, Speakman JR, Gabrielsen GW (2009b) Daily energy expenditure increases in response to low nutritional stress in an Arcticbreeding seabird with no effect on mortality. Funct Ecol 23:1081-1090

> Welcker J, Moe B, Bech C, Fyhn M, Schultner J, Speakman JR, Gabrielsen GW (2010) Evidence for an intrinsic energetic ceiling in free-ranging kittiwakes Rissa tridactyla. J Anim Ecol 79:205-213

Wells BK, Field JC, Thayer JA, Grimes CB and others (2008) Untangling the relationships among climate, prey and top predators in an ocean ecosystem. Mar Ecol Prog Ser 364:15-29

Zador SG, Piatt JF (1999) Time-budgets of common murres at a declining and increasing colony in Alaska. Condor 101:149-152

Zador SG, Parrish JK, Punt AE (2009) Factors influencing subcolony colonization and persistence in a colonial seabird, the common murre Uria aalge. Mar Ecol Prog Ser 376:283-293

Submitted: November 9, 2011; Accepted: April 8, 2012 Proofs received from author(s): July 9, 2012 